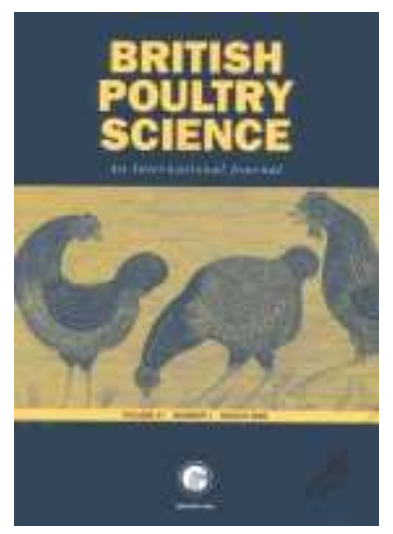

\title{
Effects of caponization on lipid and fatty acid composition of intramuscular and abdominal fat of medium-growth broilers
}

\begin{tabular}{|r|l|}
\hline Journal: & British Poultry Science \\
\hline Manuscript ID: & CBPS-2010-013.R2 \\
\hline Manuscript Type: & Original Manuscript \\
\hline Author: & 15-Oct-2010 \\
\hline & $\begin{array}{l}\text { Complete List of Authors: } \\
\text { Mepartment of Food Technology } \\
\text { Miniadis-Meimaroglou, Sofia; University of Athens, Department of } \\
\text { Chemistry } \\
\text { Symeon, George; Agricultural University of Athens, Animal } \\
\text { Breeding and Husbandry } \\
\text { Bizelis, Iosif; Agricultural University of Athens, Animal Breeding and } \\
\text { Husbandry }\end{array}$ \\
\hline Keywords: & \begin{tabular}{l} 
fatty acids, Total lipids, neutral and polar lipids, capons \\
\hline
\end{tabular} \\
\hline
\end{tabular}

\section{SCHOLARONE Manuscripts}


Copy editor:

I have edited the text as there were several parts that required substantial rewriting but I have not been through it in detail. There are also 2 small items that require information from the authors (see comment boxes): there may be others that you raise that can be addressed by the authors at the same time. Paul Hocking, 7 April 2011

\section{Effects of caponisation on lipid and fatty acid composition of intramuscular} and abdominal fat of medium-growth broilers

\section{Short title: Effects caponisation on lipid composition}

V. J. Sinanoglou ${ }^{\mathrm{a}}$, F. Mantis ${ }^{\mathrm{b}}$, S. Miniadis-Meimaroglou ${ }^{\mathrm{c}}$, G. K. Symeon ${ }^{\mathrm{d}}$ and I.

A. Bizelis ${ }^{\mathrm{d}^{*}}$

${ }^{a}$ Food Analysis Laboratory, Department of Food Technology, Technological

Educational Institution of Athens, Greece.

${ }^{\mathrm{b}}$ Laboratory of Meat and Meat products Technology and Quality Control,

Department of Food Technology, Technological Educational Institution of Athens, Greece.

${ }^{\mathrm{c}}$ Food Chemistry Laboratory, Department of Chemistry, University of Athens,

Greece.

${ }^{\mathrm{d}}$ Laboratory of Animal Breeding and Husbandry, Department of Animal Science and Aquaculture, Agricultural University of Athens, Greece

*Corresponding Author: jmpiz@aua.gr, 75, Iera odos, GR118 55, Athens,

Greece, Tel: 0030 2105294452, Fax: 00302105294442 


\begin{abstract}
1. Capons and intact male broilers were used to investigate the effects of caponisation on intramuscular fat and abdominal adipose tissue lipid classes' content and fatty acid profile.

2. Capons had significantly higher total lipid content $(\mathrm{P}<0.05)$.

3. Neutral lipids were the major fractions in intramuscular and abdominal fat but their proportions differed significantly among groups and tissues $(\mathrm{P}<0.05)$.

4. The predominant saturated, monounsaturated and polyunsaturated fatty acids in all samples were C16:0, C16:1 $\omega-9$, C18:0, C18:1 $\omega-9$, C18:1 $\omega-7$, C18:2 $\omega-6$ and C20:4 $\omega-6$.

5. Caponisation resulted in a significant $\omega-6 / \omega-3$, PUFA and PUFA/SFA ratio reduction as well as in a significant atherogenic and thrombogenic indices increase in intramuscular fat $(\mathrm{P}<0.05)$ without affecting their appropriate value for a healthy diet.
\end{abstract}

Keywords: Total lipids; neutral and polar lipids; fatty acids; capons.

\begin{abstract}
Abbreviations: MG, monoglycerides; DG, diglycerides; DHA, docosahexaenoic acid; EPA, eicosapentaenoic acid; FAME, fatty acid methyl esters; FA, fatty acids; FFA, free fatty acids; 1-PC, lyso-phosphatidylcholine; MUFA, monounsaturated fatty acids; NL, neutral lipids; PC, phosphatidylcholine; PE, phosphatidylethanolamine; PS, phosphatidylserine; PhL, phospholipids; PL, polar lipids; PUFA, polyunsaturated fatty acids; SFA, saturated fatty acids; Sph, sphingomyelin; TFA, total fatty acids; TG, triglycerides; TL, total lipids.
\end{abstract}




\section{INTRODUCTION}

Several species of birds are used for commercial production of meat (Mozdziak, 2004), but chickens have become the predominant poultry species produced globally The popularity of chicken meat popularity has grown rapidly because the remarkable increase in production efficiency has made it a widely acceptable alternative to traditional red meat, such as beef and pork (Gillipespie, 2002; Mozdziak, 2004). Chicken meat is also a low-cost product since modern selection and production techniques have reduced the age at slaughter to approximately 6 weeks with the result that feed conversion efficiency is high (Ravindran, 2004).

In recent times there has been an increase in the demand for more variety and greater quality of poultry meat products. This has led to a reappraisal of the use of traditional practices, such as caponisation (Tor et al., 2002). Caponisation produces a special type of chicken meat since it results in increased overall fatness in terms of abdominal (Cason et al., 1988), subcutaneous and intramuscular fat (Hsieh et al., 2001). The abdominal adipose tissue is the main fat depot in the body of chickens and can make up approximately $30 \%$ of the mass of major fat depots (Nir et al., 1988). On the other hand, intramuscular fat is located throughout the skeletal muscle and accounts for around $1 \%$ in poultry Pectoralis major muscle. Nevertheless, fat, whether in adipose tissue or muscle, contributes to important aspects of meat quality (marbling, tenderness, colour) and it is central to the nutritional and sensory values of the meat (Webb and O'Neill, 2008). Specifically, the increased overall fatness in capons enhances flavor, texture and meat juiciness when compared to intact cockerels (Chen et al., 2005).

\section{There have been few investigations of the influence of caponisation on the lipid} and fatty acid composition in the carcass and its nutritional value in the human diet
Deleted: Poultry refers to birds such as

Deleted: hickens, turkeys, ducks, pheasants, geese, emus, quails and related Deleted: that

Deleted: ,

Deleted: due to the predominant numbers of

Deleted: it has become synonymous to chickens.

Deleted: C

Deleted: 's

Deleted: tasty

Deleted: s

Deleted: farming duration of a broiler

Deleted: consumer's

Deleted: has rarely been investigated 
Thus, the aim of this research was to determine the lipid and fatty acid composition of intramuscular and abdominal fat of capons and intact cockerels and to evaluate the Deleted: investigation Deleted: examine effect of caponisation on lipid and fatty acid profile.

\section{MATERIALS AND METHODS}

\section{Reagents and standards}

The lipid standards used were: cholesterol, triolein, lauric acid, oleic acid, linoleic acid, 1,2-diglycerides, monoglycerides, phosphatidylcholine, phosphatidylethanolamine, lyso-phosphatidylcholine, lyso-phosphatidylethanolamine, phosphatidylserine and sphingomyelin standards of the Sigma Chemical Co (SigmaAldrich Company, Dorset, Great Britain and St. Louis, MO, USA).

Fatty acid methyl esters used as GC-FID standard mixtures were: Supelco ${ }^{\mathrm{TM}} 37$ Component FAME Mix C4-C24, $100 \mathrm{mg}$ Neat. Catalog No:18919-1AMP and Supelco PUFA No.1, Marine Source, 100 mg Neat. Catalog No:47033. All solvents used for sample preparation were of analytical grade and the solvents used for GC and MS analyses were of HPLC grade from Merck (Darmstadt, Germany). Double distilled water was used throughout this work. All reagents used were of analytical grade and they were purchased from Mallinckrodt Chemical Works (St. Louis, MO, USA) and from Sigma Chemical Co (Sigma-Aldrich Company, UK).

\section{Animal Management and Experimental Design}

The experiment was conducted in the experimental facilities of the Department of Animal Science and Aquaculture of the Agricultural University of Athens. Feathersexed male medium-growing broilers (Redbro, Hubbard SAS, France) were purchased from a local hatchery on day zero. On arrival, birds were wing-marked, 


\section{Caponisation}

Caponisation was performed at 3 weeks of age. The birds selected for surgery were deprived of feed and water for 24 and 12 hours, respectively, before the procedure. Anaesthesia was performed using Xylazine (Rompun, Bayer HealthCare, Germany) and Ketamine (Ketaset, Fort Dodge, USA) in doses of 1.5 and $23 \mathrm{mg} / \mathrm{kg}$ live weight, respectively. The mean ( \pm S.E.) live weight of the chicks was $650 \pm 19 \mathrm{~g}$. After feather removal, the incision area was prepared with povidone iodine $10 \%$ (Betadine solution, Mundipharma, Switzerland) and a $1.5 \mathrm{~cm}$ incision was performed between the two last ribs. Incomplete caponised chickens (slips) rates were $6.4 \%$. 
These birds were identified by the color and size of the combs and were removed from the experiment. Mortality rates for the whole experiment were $3.4 \%$.

\section{Slaughter procedure}

At 18 weeks of age, ten chickens per group were randomly selected and they were fasted 16 hours before slaughter. They were electrically stunned $(120 \mathrm{~V} / 50 \mathrm{~Hz}$ for $5 \mathrm{sec}$ ), killed by decapitation and left to bleed for approximately $1 \mathrm{~min}$. Afterwards, they were passed through a warm scalding vessel $\left(60^{\circ} \mathrm{C}\right.$ for $\left.2 \mathrm{~min}\right)$, a plucker $(2 \mathrm{~min})$ and were manually eviscerated. After primary cooling on air for approximately 1 hour, they were stored at $4^{\circ} \mathrm{C}$ overnight.

\section{Total lipids extraction}

Total lipids extraction was performed in Pectoralis major muscle and abdominal fat samples according to the method of Folch et al. (1957). After phase equilibration the lower chloroform layer (TL) was removed and dried in a rotary vacuum evaporator at $32^{\circ} \mathrm{C}$. The extracted lipids were redissolved in chloroform/methanol (9:1 $\mathrm{v} / \mathrm{v}$ ) and finally stored at $0^{\circ} \mathrm{C}$ until used. To prevent oxidation t-butyl-hydroquinone, at a concentration of $100 \mathrm{mg} / \mathrm{l}$, was added to all samples during preparation. Afterwards, representative aliquots of $10-12 \mathrm{mg}$ of total lipids were evaporated in preweighed vials to constant weight to determine the lipid content.

Deleted:

Deleted: , of all the above mentioned samples

Formatted: Font color: Red, English

\section{Iatroscan analysis of neutral and polar lipids}

Lipid classes were separated on silicic acid-coated quartz rods Chromarods (Type SIII) (silica gel-coated quartz rod. Iatron Labs, Tokyo, Japan) and then quantified using a thin layer chromatography-flame ionisation detection system 
(TLC-FID) (Sinanoglou et al., 2009). TLC-FID analysis was performed by an Iatroscan thin-layer chromatograph (Model MK-6 TLC / FID - FPD Analyser, Iatron Laboratories, Tokyo, Japan) equipped with a flame ionization detector and connected to a personal computer for collecting the chromatograms. Operation conditions for the Iatroscan were $160 \mathrm{~mL} \mathrm{~min}^{-1}$ hydrogen flow, $2 \mathrm{~L} \mathrm{~min}^{-1}$ air flow and $30 \mathrm{~s} /$ chromarod scanning speed. A $1 \mu \mathrm{L}$ Hamilton syringe (Hamilton Co., Reno, USA) was used to spot standards and samples. The rods were developed with a one- or two-solvent system. The neutral solvent system consisted of n-H:DE:FA (60:15:1.5 by vol.) as well as the polar solvent system of C:M:W (50:20:2. by vol.).

The determination of weight percentages of individual lipid classes was achieved using the standard curves obtained for each authentic standard ( 0.15 to 0.25 $\mathrm{mg} / \mathrm{ml}$ per lipid) under the same chromatogram conditions and development temperature. The correlation coefficients for the calibration curves of thirteen lipid classes were in all cases higher than 0.998 .

\section{Gas chromatography analysis of fatty acid methyl esters}

Fatty acid methyl esters (FAME) of total lipids were prepared according to the procedure described by Sinanoglou and Miniadis-Meimaroglou (1998). Both quantitative and qualitative analyses were performed on an Agilent 6890 Series Gas Deleted: analysis were Chromatograph equipped with a flame ionization detector. DB-23 capillary column $(60 \mathrm{~m} \times 0.25 \mathrm{~mm}$ i.d., $0.15 \mu \mathrm{m}$ film) [50\%-Cyanopropyl)-methylpolysiloxane] (Agilent Technologies, Catalogue No: 122-2361) was used. Helium was used as a carrier gas. The injector and detector temperature were $250^{\circ} \mathrm{C}$ and $260^{\circ} \mathrm{C}$ respectively. The temperature was programmed at $100^{\circ} \mathrm{C}$ for $0 \mathrm{~min}$, raised from 100 to $150^{\circ} \mathrm{C}$ by a rate of $10^{\circ} \mathrm{C} \mathrm{min}^{-1}$ and held constant at $150^{\circ} \mathrm{C}$ for $0 \mathrm{~min}$, then raised from 150 to $195^{\circ} \mathrm{C}$ by 
a rate of $2^{\circ} \mathrm{C} \min ^{-1}$ and held constant at $195^{\circ} \mathrm{C}$ for $5 \mathrm{~min}$, then raised from 195 to $210^{\circ} \mathrm{C}$ by a rate of $1^{\circ} \mathrm{C} \mathrm{min}^{-1}$ and held constant at $210^{\circ} \mathrm{C}$ for $0 \mathrm{~min}$ and finally raised from 210 to $240^{\circ} \mathrm{C}$ by a rate of $10^{\circ} \mathrm{C} \mathrm{min}^{-1}$ and held constant at $240^{\circ} \mathrm{C}$ for $5 \mathrm{~min}$. The duration of the analysis was $55.50 \mathrm{~min}$ (Sinanoglou et al., 2009).

Individual fatty acids were quantified according to the formula:

$\mu \mathrm{g}(\mathrm{FA})=$ FAME peak area $\mathrm{x}$ FAME response factor, where FAME response factors were determined according to the FAME standard chromatograms under the same chromatographic conditions, and were identified by comparison of their retention times to those of the standard mixtures.

Deleted: as

Deleted: s

Deleted: .

Deleted: $q$

In GC method, the fatty acid methyl esters

\section{Statistical analysis}

All measurements were obtained (at least) in triplicate and values were averaged and reported along with the standard error (s.e.). Data were analyzed using multifactor ANOVA fitting the treatment and the origin of fat as fixed factors. Multiple comparisons were conducted with the Tukey's honestly significant difference test. All data were analyzed with the SPSS-10 statistical software designed for Windows (Chicago, IL, USA).

\section{RESULTS}

\section{Total, neutral and polar lipid content}

Total (TL, g/100g of muscle or adipose tissue), neutral (NL) and polar (PL) lipids (mg/100mg of TL) of intramuscular fat and abdominal adipose tissue of capons and intact males are presented in Table 1.

(Table 1 presented here) 
TL content was significantly lower in the intramuscular fat than in the abdominal adipose tissue $(\mathrm{P}<0.05)$. In both intramuscular fat and abdominal adipose tissue, TL mainly consisted of NL, but in the intramuscular fat the percentage of PL was significantly higher than in the abdominal adipose tissue.

Capons had a significantly higher content of TL in intramuscular fat and the abdominal adipose tissue in comparison to intact males $(\mathrm{P}<0.05)$. Capons also had a higher NL percentage in the intramuscular fat while the opposite result was observed Deleted: exact for the abdominal adipose tissue.

\section{Neutral and polar lipid profile}

Abdominal NL of capons and intact males consisted mainly of TG (>99.5\% of total

Deleted: Capons

Deleted: abdominal NL mainly

NL) while PL mainly consisted of PC ( $>90.0 \%$ of total PL) and PE ( $>8.5 \%$ of total PL). Differences between the groups were not significant (data not shown). The neutral and polar lipid profile of intramuscular fat of capons and intact males is eleted: No Deleted: d

Deleted: was found presented on Table 2. Intramuscular NL mainly consisted of TG followed by cholesterol, FFA, DG and MG. In the intramuscular PL, PC had the highest percentage followed by PE, Sph, PS and 1-PC.

(Table 2 presented here)

The intramuscular TL of capons contained a significantly higher TG percentage $(\mathrm{P}<0.05)$ compared to those of intact males, while the opposite result was observed Deleted: exact Deleted: phenomenon for FFA, cholesterol, MG, and PL percentages. 


\section{Fatty acids}

The fatty acid (FA) profile of TL isolated from intramuscular and abdominal fat of capons and intact males is shown in Table 3. The carbon chain length of the identified fatty acids ranged from $14 \mathrm{C}$ to $24 \mathrm{C}$ and the number of double bonds from 0 Deleted: . Furthermore, to 6 .

The major fatty acids of both the abdominal and intramuscular TL of capons

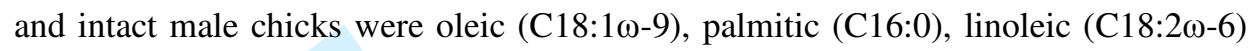

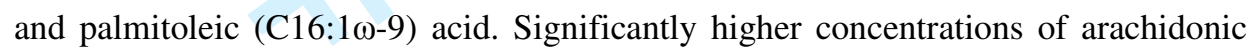
acid (C20:4 $\omega-6)$ were found in intramuscular compared to abdominal TL.

Deleted: the

Deleted: in

Deleted: ison

(Table 3 presented here)

C18:2cis-9,trans-11 comprised less than $0.1 \%$ of total fatty acids across both abdominal adipose tissue and intramuscular fat. Intramuscular TL were higher in SFA, PUFA, $\omega-3$ and $\omega-6$ fatty acids while abdominal TL were higher in MUFA. This resulted in an increased SFA/MUFA ratio in intramuscular in contrast to abdominal TL while the opposite was observed for PUFA/SFA and $\omega-6 / \omega-3$ ratios.

Deleted: exact

Deleted: result

Intramuscular TL of capons, in comparison with intact males, had significantly higher percentages of SFA and $\omega-3$ FA and lower PUFA and $\omega-6$ FA. There was no Deleted: $\mathrm{t}$ a statistically significant difference in MUFA percentages between the groups. Specifically, TL from intramuscular fat of capons were significantly higher in Deleted: capons myristic (C14:0), palmitic (C16:0), stearic (C18:0) and arachidonic (C20:4 $\omega-6)$ acid and significantly lower in linoleic (C18:2 $\omega-6)$ acid than intact males, resulting thus in Deleted: as well as Deleted: significantly lower $\omega-6 / \omega-3$ and $\mathrm{C} 16: 0 / \mathrm{C} 18: 0$ ratios. 


\section{DISCUSSION}

It is well established that caponisation results in increased body fat accumulation jn terms of both abdominal (Cason et al., 1988; Tor et al., 2002; Hsu and Lin, 2003; Chen et al., 2005; Chen et al., 2006a; Chen et al., 2006b; Miguel et al., 2008) and intramuscular fat (Tor et al., 2002; Miguel et al., 2008), The same phenomenon has been observed for bovine L. dorsi muscle intramuscular fat (Hood and Allen, 1971) but not for porcine L. dorsi muscle, even though the backfat thickness was higher in castrates in comparison to intact male pigs (Hogberg et al., 2004).

The relative importance of intramuscular fat, as far as the final product is concerned, is much higher in poultry since most of the abdominal adipose tissue is discarded during standard slaughtering conditions. To our knowledge, there is only one reference in the literature that addresses the effects of caponisation on lipid composition. In that work, Sirri et al. (2009) reported that caponisation increased SFA content of Pectoralis minor muscle while it did not affect MUFA, PUFA, $\omega-3$ and $\omega-6$ content. Цूn mammals castration was reported to significantly influence bovine L. dorsi intramuscular fatty acid composition since the SFA proportion was higher in steers whereas PUFA was higher in bulls (Clemens et al., 1973; Eichhorn et al., 1985). Moreover, steers had a lower $\omega-6 / \omega-3$ ratio, which is considered to have beneficial effects on human health (Monteiro et al., 2006). Even in comparison to 
heifers, the intramuscular fat of steers was found to have higher and lower proportions respectively of SFA and unsaturated fatty acids (Waldman et al., 1968; Terrell et al., Deleted: steers

In porcine L. dorsi intramuscular fat the effects of castration on fatty acid composition are reported to be similar. Barrows had higher proportions of SFA, especially C16:0 and C18:0, while boars had higher proportions of MUFA, PUFA, n6 and n-3 fatty acids (Hogberg et al., 2004). Moreover, in several studies, the level of unsaturation of the intramuscular fat is higher in gilts than in castrated males (Hogberg et al., 2001, 2002; Hogberg et al., 2003; Nilzen et al., 2001). Moreover, Hogberg et al. (2003) found a positive correlation between SFA and IMF and a negative correlation between unsaturated FA and IMF. Consequently, the increased level of SFA in the intramuscular fat of capons was an indirect effect of the increased intramuscular fat accumulation due to caponisation.

The ratio of PUFA to SFA is considered to be important in relation to the nutritional value of foods for human health. In the human diet, the minimum recommended value for PUFA/SFA ratio is $0.45-0.65$ (Department of Health, 1984) and lower ratios in the diet as a whole may result in increased incidents of cardiovascular disease. Thus, caponisation included a PUFA reduction and a replacement of PUFA with SFA, but without affecting the positive PUFA:SFA ratio. High levels of MUFA were observed in both intramuscular fat and abdominal adipose tissue of the experimental groups as the distribution pattern of the sum of fatty acids in TL was: MUFA $>$ SFA $>$ PUFA. MUFA of the cis-configuration, compared with SFA, are hypocholesterolemic with the advantage of not reducing HDL-cholesterol, which protects against coronary heart disease (CHD) (Mattson and Grundy, 1985).
Deleted:

Deleted: respectively

Deleted: quite

Deleted: were found to have

Deleted: lever

Deleted: with regard to

Deleted: also

Deleted: capons'

Deleted: /

Deleted: ratio 
Abdominal TL contained only traces of arachidonic acid (C20:4 $\omega-6)$ in comparison to intramuscular TL. Arachidonic acid is synthesized from linoleic acid (Machlin and Gordon, 1961). This indicates that capons and intact males probably synthesized arachidonic acid and deposited a lower percentage of it in the lipid rich tissues (abdominal fat) than in the meat. In contrast to our results, Sirri et al. (2009) reported that arachidonic acid in the intramuscular fat of Pectoralis major muscle significantly increased from capons to slips and to cocks, and this difference was attributed to the inhibition of $\Delta^{6}$-desaturate by the caponisation. In our study, capon intramuscular fat contained significantly higher arachidonic acid and significantly lower linoleic acid than intact males, which might be associated with the commercial diet and/or the metabolism of the birds. The absence or the trace amounts of C20 and C22 polyunsaturated fatty acids (PUFA) in abdominal TL resulted from the low proportion of PL $(<5 \%)$ in the TL fraction and the possible failure of abdominal adipose tissue to incorporate these fatty acids into the triglycerides.

One method of estimating food quality, in terms of lipids, is the use of atherogenic and thrombogenic indices, as proposed by Ulbricht and Southgate (1991).

The atherogenic index of abdominal fat for capons and intact males respectively was 0.35 and 0.37 and the indexes for intramuscular fat were 0.38 and 0.43 . The thrombogenic index of capons and intact males for abdominal fat was 0.68 and 0.70 and for intramuscular fat it was 0.71 and 0.83 . Caponization, in general, induced an increase in both indices but remained lower than the appropriate value for a healthy diet recommended by Ulbricht and Southgate (1991), Žlender et al. (2001) reported an atherogenic index of 0.49 and 0.51 for the semitendinosus and triceps brachii muscles of Simmental and Brown bulls. Vacca et al. (2008) reported that indices of atherogenicity and thrombogenicity in muscles of Mouflon $\times$ Sarda and Sarda

Deleted: with

Deleted: IMF

Deleted: to
Deleted: A solid way

\begin{tabular}{|l|}
\hline Deleted: Atherogenic \\
\hline Deleted: males \\
\hline Deleted: abdominal fat ranged from \\
\hline Deleted: to \\
\hline Deleted: while \\
\hline Deleted: the respective range was \\
\hline Deleted: ranged between \\
\hline Deleted: the respective range \\
\hline Deleted: - \\
\hline Deleted: their numbers \\
\hline Deleted: one which according to \\
\hline Deleted: is the appropriate value for a \\
healthy diet \\
\hline Deleted: AI \\
\hline Deleted: from \\
\hline Deleted: to \\
\hline
\end{tabular}


suckling lambs varied between 0.9 and 1.1 whereas, Valfre et al. (2003) reported atherogenic indexes ranging from 0.25 to 0.45 and thrombogenic indexes of 0.45 to 1.35 for fish meat.

Cholesterol is a nutritionally important component of meats. After having taken into consideration the cholesterol values of capons and intact males intramuscular fat, their contribution to the recommended maximum cholesterol intake can be calculated through the consumption of $100 \mathrm{~g}$ of capon and intact male muscular tissue. This contribution represented $14 \%$ and $11 \%$, respectively, of the recommended maximum cholesterol intake (300_mg per day; De Backer et al., 2003).

On comparing capons and intact males, the results indicated that caponisation had a considerable effect on the total fat and fatty acid content. As consumers are looking for a diet with low fat and high levels of PUFA, caponisation indicated an improved quality of meat, including a good fatty acid profile, low cholesterol content and PUFA:SFA ratio, satisfactory atherogenic and thrombogenic indexes, and a reduction in the ratio of $\omega-6 / \omega-3$ fatty acids. However, the higher production cost due to the caponization procedure would have to be covered by the premium prices that these products have in the market.

\begin{tabular}{|l|}
\hline Deleted: \\
\hline Deleted: while \\
\hline Deleted: AI \\
\hline Deleted: as well as \\
\hline Deleted: TI from \\
\hline Deleted: some \\
\hline
\end{tabular}

Deleted: 10.96

\begin{tabular}{l} 
Deleted: promising \\
Deleted: quality \\
Deleted: / \\
Deleted: AI \\
\hline Deleted: TI \\
Deleted: as well as \\
Deleted: ratio reduction \\
Deleted: Moreover is \\
\hline
\end{tabular}

Besides the promising meat quality of capons there is also an ethical concern regarding the practical administration of the caponization technique on everyday practice. In the more distant past, capons were produced by surgery without anesthetic, which was banned for welfare reasons, then later by hormonal means, which was banned because of residues in the meat. The surgical technique could still be unacceptable in many countries because a degree of distress is inevitable even Deleted: small when performed under anesthesia. In time, of course, it may be that capons can be 
produced without stress by genetic modification or by chemical means without the hormonal residues, but that is for the future.

\section{ACKNOWLEDGEMENTS}

We are grateful to Miss Dido-Maria Meimaroglou for the valuable help with the manuscript. In addition, George K. Symeon wishes to thank the Greek State Scholarships Foundation for its financial support during this study. 


\section{REFERENCES}

CASON, J.A., FLETCHER, D.L. \& BURKE, W.H. (1988) Research note: Effects of caponisation on broiler growth. Poultry Science, 67: 979-981.

CHEN, K., CHI, W. \& CHIOU, P. (2005) Caponisation and testosterone implantation effects on blood lipid and lipoprotein profile in male chickens. Poultry Science, 84: $547-552$.

CHEN, K.L., TSAY, S.M., LEE, T.Y. \& CHIOU, P.W.S. (2006b) Effects of caponisation and different exogenous androgen on the bone characteristics of male chickens. Poultry Science, 85: 1975-1979.

CHEN, K.L., CHANG, M.H., TSAY, S.M., HURNG, H.Y. \& CHIOU, P.W.S. (2006a) Effects of caponisation on bone characteristics and histological structure in chickens. Asian Australasian Journal of Animal Science, 19: 245 (Abstr.).

CLEMENS, E., ARTHAUD, V., MANDIGO, R. \& WOODS, W. (1973) Fatty acid composition of bulls and steers as influenced by age and dietary energy level. Journal of Animal Science, 37: 1326-1331.

DE BACKER, G., AMBROSIONI, E., BORCH-JOHNSEN, K., BROTONS, C., CIFKOVA, R., DALlONGEVILle, J., EBRAHIM, S., FAERGEMAN, O., GRAHAM, I., MANCIA, G., MANGER CATS, V., ORTH-GOMÉR, K., PERK, J., PYÖRÄLÄ, K., RODICIO, J. L., SANS, S., SANSOY, V., SECHTEM, U., SILBER, S., THOMSEN, T. \& WOOD, D. (2003) European guidelines on cardiovascular disease prevention in clinical practice: Third Joint Task Force of European and other Societies on Cardiovascular Disease Prevention in Clinical Practice (constituted by representatives of eight societies and by invited experts). European Heart Journal, 24: 1601-1610. 
EICHHORN, J.M., BAILEY, C.M. \& BLOMQUIST, G.J. (1985) Fatty Acid Composition of Muscle and Adipose Tissue from Crossbred Bulls and Steers. Journal of Animal Science, 61: 892-904.

FOLCH, J., LEES, M. \& SLOANE STANLEY, G.H. (1957) A simple method for the isolation and purification of total lipids from animal tissues. Journal of Biological Chemistry, 226: 497-509.

GILLIPESPIE, J.R. (2002) Modern Livestock and Poultry Production, 6th ed. Clifton Park, NY: Delmar Publishers.

HOGBERG, A., PICKOVA, J., ANDERSSON, K. \& LUNDSTROM, K. (2003) Fatty acid composition and tocopherol content of muscle in pigs fed organic and conventional feed with different n6/n3 ratios, respectively. Food Chemistry, 80: 177186.

HogberG, A., PiCKOVA, J., BABOL, J., ANDERSSON, K. \& DUTTA, P.C. (2002) Muscle lipids, vitamins E and A, and lipid oxidation as affected by diet and RN genotype in female and castrated male Hampshire crossbreed pigs. Meat Science, 60: $411-420$.

HOGBERG, A., PICKOVA, J., DUTTA, P.C., BABOL, J. \& BYLUND, A.C. (2001) Effect of rearing system on muscle lipids of gilts and castrated male pigs. Meat Science, 58: 223-229.

HOGBerG, A., PICKOVA, J., STERN, S., LUNDSTROM, K. \& BYLUND, A.C. (2004) Fatty acid composition and tocopherol concentrations in muscle of entire male, castrated male and female pigs, reared in an indoor or outdoor housing system. Meat Science, 68: 659-665. 
HOOD, R.L. \& ALLEN, E. (1971) Influence of sex and post-mortem aging on intramuscular and subcutaneous bovine lipids. Journal of Food Science, 36: 786-790.

HSIEH, C.Y., CHEN, K.L. \& CHIOU, P.W.S. (2001) The lipoprotein composition and structure of capon and incomplete caponized Taiwan country chicken. Journal of the Chinese Society of Animal Science, 30: 229 (Abstr).

HSU, J.C. \& LIN, C.Y. (2003) Influence of caponisation on the carcass characteristics in Taiwan country chicken cockerels. Asian-Australasian Journal of Animal Science, 16: 575 (Abstr.).

MACHLIN, L.J. \& GORDON, R.S. (1961) Effect of dietary fatty acids and cholesterol on growth and fatty acid composition of the chicken. Journal of Nutrition, 75: 157 .

MATTSON, F.H. \& GRUNDY, S.M. (1985) Comparison of effects of saturated, monounsaturated and polyunsaturated fatty acids on plasma lipids and lipoproteins in man. Journal of Lipid Research, 26: 194-202.

MIGUEL, J.A., CIRIA, J., ASENJO, B. \& CALVO, J.L. (2008) Effect of caponisation on growth and on carcass and meat characteristics in Castellana negra native Spanish chickens. Animal, 2: 305-311.

MONTEIRO, A.C.G., SANTOS-SILVA, J., BESSA, R.J.B., NAVAS, D.R. \& LEMOS, J.P.C. (2006) Fatty acid composition of intramuscular fat of bulls and steers. Livestock Production Science, 99: 13-19.

MOZDZIAK, P. (2004) Nutrition of meat animals/Poultry. In: Encyclopaedia of Meat Sciences, (p.p. 1296-1302). North Carolina State University, Raleigh, NC, USA, Elsevier Ltd. 
NILZEN, V., BABOL, J., DUTTA, P.C., LUNDEHEIM, N., ENFALT, A.C. \& LUNDSTROM, K. (2001) Free range rearing of pigs with access to pasture grazingeffect on fatty acid composition and lipid oxidation products. Meat Science, 58: 267275.

NIR, I., NITSAN, Z. \& KEREN-ZVI, S. (1988) Fat deposition in birds. In: Leanness in domestic birds: Genetic, metabolic and hormonal aspects (Leclercq, B. and Whitehead, C.C., eds.) pp. 141-174, Butterworth and Company, London, U.K.

RAVINDRAN, V. (2004) Nutrition of meat animals/Poultry. In: Encyclopaedia of Meat Sciences, (p.p. 925-933). Massey University, Palmerstone North, New Zealand, Elsevier Ltd.

SINANOGLOU, V.J. \& MINIADIS-MEIMAROGLOU, S. (1998) Fatty acid of neutral and polar lipids of (edible) Mediterranean cephalopods. Food Research International, 31: 467-473.

SINANOGLOU, V.J., PAPADAS, G., MEIMAROGLOU, D. \& MINIADISMEIMAROGLOU, S. (2009) Separation and quantification of marine lipids by modified Iatroscan-TLC-FID and GC-FID analysis. Application to total, neutral and polar lipids and their fatty acids extracted from raw and fried Spicara smaris. In Proceedings of the $6^{\text {th }}$ International Conference "Instrumental Methods of Analysis IMA 2009"(p. 74).

SIRRI, F., BIANCHI, M., PETRACCI, M. \& MELUZZI, A. (2009) Influence of partial and complete caponisation on chicken meat quality. Poultry science, 88: 14661473 
TERRELL, R.N., SUESS, G.G. \& BRAY, R.W. (1969) Influence of sex, liveweight and anatomical location on bovine Lipids. I. Fatty Acid Composition of Subcutaneous and Intramuscular Fat Depots. Journal of Animal Science, 28: 449-453.

TOR, M., ESTANY, J., VIllalbA, D., MOlinA, E. \& CUBILO, D. (2002) Comparison of carcass composition by parts and tissues between cocks and capons. Animal Research, 51: 421-31.

ULBRICH, T.L.V. \& SOUTHGATE, D.A.T. (1991) Coronary heart disease seven dietary factors. Lancet, 338: 985-992.

VACCA, G.M., CARCANGIU, V., DETTORI, M.L., PAZZOLA, M., MURA, M.C., LURIDIANA, S. \& TILLOCA, G. (2008) Productive performance and meat quality of Mouflon $\times$ Sarda and Sarda $\times$ Sarda suckling lambs. Meat Science, 80: 326-334.

VALFRE, F., CAPRINO, F. \& TURCHINI, G.M. (2003) The health benefit of seafood. Veterinary Research Communications, 27: 507-512.

WALDMAN, R.C., SUESS, G.G. \& BRUNGARDT, V.H. (1968) Fatty acids of certain bovine tissue and their association with growth, carcass and palatability traits. Journal of Animal Science, 27: 632-635.

WEBB, E.C. \& O'NEILL, H.A. (2008) The animal fat paradox and meat quality. Review. Meat Science, 80: 28-36.

ZEMBAYASHI, M., NISHIMURA, K., LUNT, D.K. \& SMITH, S.B. (1995) Effect of breed type and sex on the fatty acid composition of subcutaneous and intramuscular lipids of finishing steers and heifers. Journal of Animal Science, 73: 3325-3332. 
ŽLENDER, B., GAŠPERLIN, L. \& POLAK, T. (2001) Fatty acid composition of intramuscular fat in three muscles of Simmental and Brown bulls. Proceedings of the $47^{\text {th }}$ international congress of meat science and technology (Vol. 1, pp. 190-191). 